\title{
Novel Mixed-Metal Alkoxide Clusters of Lanthanide and Sodium: Synthesis and Extremely Active Catalysts for the Polymerization of $\varepsilon$-Caprolactone and Trimethylene Carbonate
}

\author{
Hongting Sheng, ${ }^{a}$ Fan $X u,{ }^{a}$ Yingming Yao, ${ }^{a}$ Yong Zhang, ${ }^{a}$ Qi Shen ${ }^{\text {a,b }}$ \\ a. Key Laboratory of Organic Synthesis, Jiangsu Province, Department of \\ Chemistry and Chemical Engineering, Suzhou University, Suzhou, 215123 China. \\ b. Laborarory of Organometallic Chemistry, Shanghai Institute of Organic \\ Chemistry, Chinese Academia Sinica, Shanghai, 200032.
}

\section{Experimental Section}

General Procedures. All manipulations were performed under argon, using the standard Schlenk techniques. THF and toluene were distilled from sodium benzophenone ketyl before use. $\varepsilon$-CL was purchased from Acros, dried over $\mathrm{CaH}_{2}$ for $48 \mathrm{~h}$, and distilled under reduced pressure. TMC was prepared according to literature. Lanthanide metal analyses were performed by EDTA titration with an xylenol orange indicator and a hexamine buffer. Carbon and hydrogen analyses were performed by direct combustion with a Carlo-Erba EA-1110 instrument. The IR spectra were recorded with a Nicolet-550 FT-IR spectrometer as $\mathrm{KBr}$ pellets. The melting points of clusters were measured in sealed capillaries and uncorrected. ${ }^{1} \mathrm{H}$ NMR spectra were obtained on an INOVA-400MHz apparatus, and referenced to d-benzene. Molecular weights and molecular weight distributions were determined against polystyrene standards by gel permeation chromatography (GPC) at $40{ }^{\circ} \mathrm{C}$ on a Water 1515 apparatus with three HR columns (HR-1, HR-2, and HR-4) using THF as the eluent.

$\left[\mathrm{Nd}_{2} \mathrm{Na}_{\mathbf{8}}\left(\mathrm{OCH}_{2} \mathrm{CH}_{2} \mathrm{NMe}_{2}\right)_{\mathbf{1 2}}(\mathrm{OH})_{2}\right]$ (1). A Schlenk flask was charged with $\mathrm{Na}(0.32 \mathrm{~g}$, $14 \mathrm{mmol})$, THF (25 mL) and a stir bar. This solution was added $\mathrm{HOCH}_{2} \mathrm{CH}_{2} \mathrm{NMe}_{2}$ (1.2ml, $12 \mathrm{mmol}$ ), then the reaction immediately gave $\mathrm{H}_{2}$ and $\mathrm{NaOCH}_{2} \mathrm{CH}_{2} \mathrm{NMe}_{2}$. After $24 \mathrm{~h}$, a pale-gray slurry of $\mathrm{NdCl}_{3}(0.50 \mathrm{~g}, 2 \mathrm{mmol})$ in $15 \mathrm{ml}$ THF was added to the $\mathrm{NaOCH}_{2} \mathrm{CH}_{2} \mathrm{NMe}_{2}$. The solution was stirred for $2 \mathrm{~h}$ at room temperature and then 
$\mathrm{NaOH}(0.08 \mathrm{~g}, 2 \mathrm{mmol})$ was added. The resulting solution was stirred for another $48 \mathrm{~h}$ and removed by vacuum. The residue was extracted with toluene and $\mathrm{NaCl}$ was removed by centrifugation. After the extracts were concentrated, blue crystals were obtained at the room temperature for few days. Yield: $1.14 \mathrm{~g}$ (73\% based on $\mathrm{Nd}) . \mathrm{mp}$ 220-222 ${ }^{\circ} \mathrm{C}$ (dec). Elemental analysis(\%) calcd. for $\mathrm{C}_{48} \mathrm{H}_{122} \mathrm{~N}_{12} \mathrm{Na}_{8} \mathrm{O}_{14} \mathrm{Nd}_{2}(1563.98 \mathrm{~g}$ $\mathrm{mol}^{-1}$ ): C 36.86, H 7.86, N 10.75, Nd 18.45; Found: C 36.82, H 7.91, N 10.78, Nd 18.43\%. IR (KBr pellet, $\mathrm{cm}^{-1}$ ): 3434(s), 2947 (m), 2820 (m), 2778 (s), 1670 (s), 1458 (s), 1308 (s), 1096 (s), 1053 (w), 949 (m), 879 (m), 829 (w), 783 (w), 675 (w), 559 (m).

$\left[\mathrm{Sm}_{2} \mathrm{Na}_{8}\left(\mathrm{OCH}_{2} \mathrm{CH}_{2} \mathrm{NMe}_{2}\right)_{12}(\mathrm{OH})_{2}\right]$ (2). By the same procedure as that for $\mathbf{1}, \mathbf{2}$ was prepared from $\mathrm{SmCl}_{3}(0.51 \mathrm{~g}, 2 \mathrm{mmol}), \mathrm{NaOCH}_{2} \mathrm{CH}_{2} \mathrm{NMe}_{2}$ and $\mathrm{NaOH}$ as while crystals. Yield: 1.25 g (79\% based on Sm). m.p.: 228-231 ${ }^{\circ} \mathrm{C}$ (dec.) Elemental analysis(\%) calcd. for $\mathrm{C}_{48} \mathrm{H}_{122} \mathrm{~N}_{12} \mathrm{Na}_{8} \mathrm{O}_{14} \mathrm{Sm}_{2}\left(1576.20 \mathrm{~g} \mathrm{~mol}^{-1}\right)$ : C, 36.58; H, 7.80; N, 10.66; Sm, 19.08; Found: C, 36.54; H, 7.81; N, 10.70; Sm, 19.10\%. IR (KBr pellet, $\mathrm{cm}^{-1}$ ) 3434(s), 2947 (m), 2854 (w), 2820 (m), 2778 (m), 1670 (m), 1454 (s), 1307 (s), 1099 (m), 1049 (m), 949 (m), 879 (m), 829 (w), 779 (w), 567 (m), 536 (m).

$\left[\mathrm{Y}_{2} \mathrm{Na}_{8}\left(\mathrm{OCH}_{2} \mathrm{CH}_{2} \mathrm{NMe}_{2}\right)_{12}(\mathrm{OH})_{2}\right](3)$. By the same procedure as that for $\mathbf{1 ,} 3$ was prepared from $\mathrm{YCl}_{3}(0.39 \mathrm{~g}, 2 \mathrm{mmol}), \mathrm{NaOCH}_{2} \mathrm{CH}_{2} \mathrm{NMe}_{2}$ and $\mathrm{NaOH}$ as while crystals. Yield: 1.10 g (76\% based on Y). m.p.: $209-210{ }^{\circ} \mathrm{C}$ (dec.) Elemental analysis(\%) calcd. for $\mathrm{C}_{48} \mathrm{H}_{122} \mathrm{~N}_{12} \mathrm{Na}_{8} \mathrm{O}_{14} \mathrm{Y}_{2}\left(1453.30 \mathrm{~g} \mathrm{~mol}^{-1}\right)$ : C, 39.67; H, 8.46; N, 11.57; Y, 12.24; Found: C, 39.65; H, 8.48; N, 11.60; Y, 12.28\%. ${ }^{1} \mathrm{H}$ NMR $\left(\mathrm{C}_{6} \mathrm{D}_{6} \mathrm{ppm}\right): 2.27$ (s, 54H, $\left.\mathrm{N}\left(\mathrm{CH}_{3}\right)_{2}\right), 2.42\left(\mathrm{~s}, 18 \mathrm{H}, \mathrm{N}\left(\mathrm{CH}_{3}\right)_{2}\right), 2.47\left(\mathrm{~s}, 18 \mathrm{H}, \mathrm{CH}_{2} \mathrm{~N}\right), 2.59\left(\mathrm{~s}, 6 \mathrm{H}, \mathrm{CH}_{2} \mathrm{~N}\right)$,

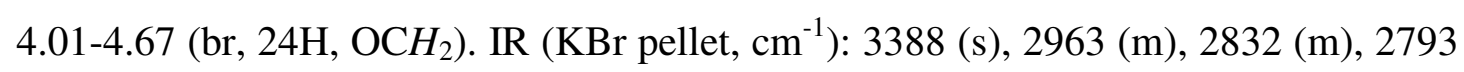
(m), 1651 (s), 1458 (s), 1234 (m), 1157 (m), 1034 (w), 941 (w), 879 (m), 633 (m).

$\left[\mathrm{Ho}_{2} \mathrm{Na}_{8}\left(\mathrm{OCH}_{2} \mathrm{CH}_{2} \mathrm{NMe}_{2}\right)_{12}(\mathrm{OH})_{2}\right](4)$. By the same procedure as that for $\mathbf{1}, \mathbf{4}$ was prepared from $\mathrm{HoCl}_{3}(0.54 \mathrm{~g}, 2 \mathrm{mmol}), \mathrm{NaOCH}_{2} \mathrm{CH}_{2} \mathrm{NMe}_{2}$ and $\mathrm{NaOH}$ as pale yellow crystals. Yield: $1.04 \mathrm{~g}$ (65\% based on Ho). mp $230-233{ }^{\circ} \mathrm{C}$ (dec). Elemental analysis(\%) calcd. for $\mathrm{C}_{48} \mathrm{H}_{122} \mathrm{~N}_{12} \mathrm{Na}_{8} \mathrm{O}_{14} \mathrm{Ho}_{2}\left(1605.36 \mathrm{~g} \mathrm{~mol}^{-1}\right)$ : C 35.91, H 7.66, N 10.47, Ho 20.55; Found: C 35.83, H 7.68, N 10.49, Ho 20.58\%. IR (KBr pellet, $\mathrm{cm}^{-1}$ ): 
3388 (s), 2956 (m), 2832 (w), 2794 (w), 1652 (s), 1459 (s), 1227 (s), 1157 (s), 1088 (w), 1034 (m), 949 (w), 879 (m), 733 (m), 632 (m), 556 (m), 509 (m).

X-Ray Crystallography. Suitable single crystals of clusters 1, 2 and 4 were sealed in a thin-walled glass capillary respectively for determining the single-crystal structure. Intensity data were collected on a Rigaku Mercury CCD area detector in $\omega$ scan mode using Mo K $\alpha$ radiation $(\lambda=0.71070 \AA$ ). The diffracted intensities were corrected for Lorentz polarization effects and empirical absorption corrections. The structures were solved by direct methods and refined by full-matrix least-squares procedures based on $|F|^{2}$. All the non-hydrogen atoms were refined anisotropically. The hydrogen atoms

were all generated geometrically $(\mathrm{C}-\mathrm{H}$ bond lengths fixed at $0.95 \AA$ ), assigned appropriate isotropic thermal parameters, and allowed to ride on their parent carbon atoms. All the $\mathrm{H}$ atoms were held stationary and included in the structure factor calculation in the final stage of full-matrix least-squares refinement. The structures were solved and refined using SHELEXL-97 program.

\section{Typical polymerization procedure}

All polymerizations were carried out in $50 \mathrm{~mL}$ Schlenk flask under dry Ar atmosphere. A typical polymerization reaction was given below. A $50 \mathrm{~mL}$ schlenk flask equipped with a magnetic stir bar was charged with a solution of $1 \mathrm{~mL} \varepsilon$-CL in Toluene (9.91 $\mathrm{mL})$. To this solution was added $0.09 \mathrm{~mL}$ solution of cluster 1 in Toluene $\left(1.0 \times 10^{-2}\right.$ M) using rubber septum and syringe. The contents of the flask were then vigorous stirred for $1 \mathrm{~min}$ at $20^{\circ} \mathrm{C}$. The polymerization was quenched by ethanol with $5 \% \mathrm{HCl}$, precipitated from ethanol, washed with ethanol three times and dried in vacuum at room temperature overnight. The polymer yield was determined gravimetrically.

\section{Oligomer for End Group Analysis}

The oligomerization of $\varepsilon$-CL was carried out with cluster $\mathbf{1}$ in toluene at $20^{\circ} \mathrm{C}$ under the condition of $[\varepsilon-\mathrm{CL}] /[$ initiator] (mole ratio) of 30 . The reaction was terminated by adding $1 \mathrm{~mL}$ of $5 \% \mathrm{HCl} / \mathrm{PrOH}$ after $2 \mathrm{~h}$. The oligomer was precipitated from ethanol. The product was dissolved in THF, followed by precipitation in ethanol. After filtration, the white product was dried in vacuum. 